\title{
Infection associated with modern surgical procedures
}

\author{
D. SHAW \\ M.B., CH.B. \\ Research Fellow in Surgery, Department of Surgery, University of Dundee
}

\begin{abstract}
Summary
In postoperative wound infections due to Escherichia coli, $59 \%$ of the sepsis was caused by ten $\mathrm{O}$-serotypes. For each serotype, except 06 , the frequency of sepsis mirrors the frequency of carriage. Endogenous wound infection: evidence was presented but not discussed. Eleven patients had wound infections due to serotype O6, five were carriers of this serotype at the time of operation. Serotype $O 6$ occurred significantly more frequently in wounds than in carriage specimens. In this study the strains showed enhanced infectivity in wounds.
\end{abstract}

I would like to introduce my talk today with a statement and a sub-title.

The statement, 'Postoperative wound sepsis is an infectious disease of multifactorial aetiology.' A more fashionable term would be 'communicable disease'. The incidence in general surgical units ranges from $5 \%$ in a new unit with $40 \%$ of the patients in singlebedded rooms. modern theatres and plenum ventilation (Davidson et al., 1971) to $10 \%$ in the older types of unit with Nightingale wards, intermittent overcrowding and theatres of poor design. The latter figure refers to the incidence in Professor $\mathbf{D}$. $M$. Douglas's unit in Dundee. This range is for sepsis with at least some degree of morbidity. The inclusion of minor sepsis doubles these figures. Surgical wound sepsis is important to the individual patient in terms of morbidity and occasionally mortality. Important to the surgeon because the effect of a well-executed operation can be substantially diminished, and a septic wound is potentially a continuous source of cross-infection. Important to us all as doctors and patients because of the considerable additional cost to the National Health Service.

My sub-title is 'A study of Escherichia coli Oserotypes isolated from postoperative septic wounds'. I am not speaking about the multitude of facets covered by the general title, because I believe specific topics such as Gram-negative infections are of more general interest.

The Public Health Laboratory Service (1960) Survey showed patients with septic wounds yielding coliform organisms only, have an excess stay in hospital of 6.5 days; slightly longer than those whose wounds yield only staphylococci. Winterbauer, Turk \& Petersdorf (1965) said 'Escherichia coli is the most common organism associated with Gramnegative hospital acquired infection'. Approximately $50 \%$ of postoperative wound infection in our unit is due to Gram-negative organisms and the commonest of these is Esch. coli. A similar finding was reported by Quick \& Brogan (1968). In the ward these organisms are most frequently associated with abdominal operations and because of this it is generally assumed the infections are endogenous in nature. However, as pointed out by Williams et al. in 1966 'Our understanding of their epidemiology is still far more superficial than that for staphylococci or streptococci'.

Our understanding of the epidemiology of Esch. coli infection of the urinary tract has been advanced by numerous studies in recent years, but there is little published work on wound infections. We need to find out what proportion of Esch. coli wound infections are endogenous; whether or not the frequency of individual serotypes in wounds is equal to the frequency of carriage in patients. If this were so, it would suggest that the reservoir for wound sepsis is the patient population. Whether the frequency of occurrence of some serotypes in wounds is higher than that of the frequency of carriage, which would suggest that these particular serotypes had some form of special pathogenicity, unless there had been an outbreak of cross-infection involving these particular organisms.

The aim of my research is firstly to try to establish whether or not strains of Esch. coli isolated from the patient at the time of operation are of the same serotype as those causing subsequent wound sepsis in that patient. That is, to find out what proportion of Esch. coli infections are endogenous. Secondly, to establish whether or not the frequency of a specific serotype in wounds is the same as the frequency of carriage by patients at the time of operation. I have some evidence for endogenous infection but I will deal with this in detail elsewhere when complete results of the experiments are available. I would now like to deal with the second part of the project.

Esch. coli has a complicated antigenic structure. It was defined by Kauffman (1969) and his colleagues 
in the 1940s. This Gram-negative bacillus has somatic (O) antigens situated in the lipopolysaccharide of the cell wall and flagellar $(\mathrm{H})$ antigens associated with the peritrichous flagellae of the motile strains. There are in addition in most strains, but especially those isolated from pathological material (Vahlne, 1945) an envelope or sheath (K) antigen overlying the somatic (O) antigen. Some 149 Oserotypes, ninety $\mathrm{K}$-serotypes and forty-nine $\mathrm{H}$ serotypes have been recognized. Ideally one would wish to classify each organism for the $\mathrm{O}, \mathrm{K}$ and $\mathrm{H}$ antigens and further it is of value to use biotyping to distinguish strains within known serotypes as shown by Bettleheim \& Taylor (1969). A considerable amount of useful epidemiological evidence has been obtained from using a few $\mathrm{O}$-antisera. Vahlne (1945) and Leppänen(1958)studying excised inflamed viscera and numerous studies of urinary tract infection have shown that a small number of O-serotypes are responsible for a high percentage of infections. Therefore, I decided to select ten serotypes for study. They were selected on the basis of those most frequently reported in the records of the Salmonella Reference Laboratory at Colindale and in the recent literature on urinary tract infection. The ones selected are: $\mathrm{O} 1$, O2, O4, O6, O7, 08, O15, O18ac, 025 and 075.

\section{Methods}

The present study was carried out in the Professorial Surgical Unit of the Dundee Royal Infirmary and in the Department of Bacteriology of the University of Dundee.

Wounds were observed by me at the time they were dressed by the nursing staff and all data collected on a card for each patient.

Specimens were obtained from patients having an operation on the gastro-intestinal tract or those requiring abdominal incisions-these were taken on a random basis. Serum-coated swabs were used to obtain nasal specimens from the anterior nares and perineal specimens. These were taken immediately before the patient went to theatre. During the operation a swab of the intestine, bowel, or viscera was taken immediately it was opened. Wound swabs were obtained whenever there was evidence of sepsis. My definition of grades of sepsis is shown in Table 1. You will see that Grade 1 is for minor sepsis and Grades 2 and 3 are for significant sepsis. Marginal

TABLE 1. Definition of the grades of wound sepsis

Grade 1 A stitch abscess or sepsis of the wound of comparable size. Healing within $24-48 \mathrm{hr}$

Grade 2 Discharge of pus sufficient to moisten a $4^{\prime \prime} \times 4^{\prime \prime}$ surgical gauze swab in $24 \mathrm{hr}$

Grade 3 Discharge of pus greater than Grade 2, the wound requiring to be dressed more than once in $24 \mathrm{hr}$ erythema and clear exudate were not accepted as signs of sepsis. Specimens were examined on the day they were taken, with few exceptions.

All specimens except nasal swabs were cultured on blood, salt and MacConkey agar plates. MacConkey agar was omitted from the examination of the nasal swabs. Staphylococcal species were identified using the slide coagulase test. Lactose fermenting organisms were confirmed as being Esch. coli by fermentation of lactose and glucose, by the production of indole and failure to produce urease or to utilize citrate.

The presence of any of the ten specific $\mathrm{O}$-serotypes being sought was confirmed by tube-dilution agglutination tests using laboratory prepared antisera standardised with known serotypes $\mathrm{O} 1$ to $\mathrm{O} 149$.

\section{Results and discussion}

I would now like to present some of the results to you and it will be easier if I discuss the significance at the same time.

The results of serotyping are shown in Table 2. Esch. coli were isolated from 159 perineal specimens, of these, eighty-three could be serotyped with the ten antisera being used. They were isolated from 124 specimens taken at operation and seventy-one could be serotyped. Wound specimens yielded seventy-five of these organisms and forty-four were serotyped.

In comparing the frequency of the isolations from the perineal and bowel specimens, with the frequency of the isolations from the wound specimens, for each serotype, it was found there is no appreciable difference between carriage and sepsis for serotypes 01 ,

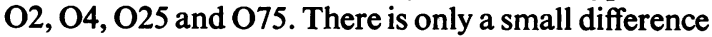
for serotypes 07,08 and 015.

The frequency for O18ac in wounds is far less than the carriage frequency, but the number of isolations from wound specimens was too small to justify statistical analysis. However, there is a much higher frequency of isolation of $\mathrm{O} 6$ from wounds compared with the carriage frequency. This difference is statistically significant by the $\chi^{2}$ test. Therefore, with the exception of $\mathrm{O} 6$ and possibly $\mathrm{O} 18 \mathrm{ac}$, the frequency of occurrence in wounds is the same as the frequency of carriage for the serotypes. I will now consider this last observation, but I will return to the question of serotype $\mathrm{O6}$ quite shortly.

In the interpretation of the results of studies of urinary tract infections there is disagreement as to whether commonly isolated O-types have properties which enhance their pathogenicity or whether their occurrence as the infecting organism reflects their frequency of carriage in the bowel. A recent leading article in the Lancet (1971) supports the view that the commonly isolated $\mathrm{O}$-types are most pathogenic and I believe this to be true, because in the present series nearly $60 \%$ of the Esch. coli wound sepsis was due to ten O-serotypes. 
TABLE 2. O-serotypes of Esch. coli isolated from specimens

\begin{tabular}{|c|c|c|c|c|c|c|}
\hline \multirow[b]{2}{*}{ Serotype } & \multicolumn{2}{|c|}{ Perineal specimens } & \multicolumn{2}{|c|}{ Operation specimens } & \multicolumn{2}{|c|}{ Wound specimens } \\
\hline & $\begin{array}{l}\text { Number of } \\
\text { isolations }\end{array}$ & $\begin{array}{c}\text { Carriage } \\
\text { frequency }(\%)\end{array}$ & $\begin{array}{l}\text { Number of } \\
\text { isolations }\end{array}$ & $\begin{array}{c}\text { Carriage } \\
\text { frequency }(\%)\end{array}$ & $\begin{array}{l}\text { Number of } \\
\text { isolations }\end{array}$ & $\begin{array}{c}\text { Frequency } \\
(\%)\end{array}$ \\
\hline $\begin{array}{l}01 \\
02 \\
04 \\
06 \\
07 \\
08 \\
015 \\
018 \text { ac } \\
025 \\
075\end{array}$ & $\begin{array}{r}14 \\
15 \\
5 \\
9 \\
3 \\
5 \\
4 \\
13 \\
5 \\
10\end{array}$ & $\begin{array}{l}8 \cdot 8 \\
9 \cdot 4 \\
3 \cdot 1 \\
5 \cdot 7 \\
1 \cdot 9 \\
3 \cdot 1 \\
2 \cdot 5 \\
8 \cdot 2 \\
3 \cdot 1 \\
6 \cdot 3\end{array}$ & $\begin{array}{r}10 \\
11 \\
3 \\
9 \\
6 \\
8 \\
7 \\
9 \\
3 \\
5\end{array}$ & $\begin{array}{l}8 \cdot 0 \\
8 \cdot 8 \\
2 \cdot 4 \\
7 \cdot 2 \\
4 \cdot 8 \\
6 \cdot 4 \\
5 \cdot 6 \\
7 \cdot 2 \\
2 \cdot 4 \\
4 \cdot 0\end{array}$ & $\begin{array}{r}5 \\
6 \\
2 \\
11 \\
4 \\
4 \\
1 \\
2 \\
4 \\
5\end{array}$ & $\begin{array}{r}6 \cdot 8 \\
8 \cdot 0 \\
2 \cdot 7 \\
14 \cdot 7 \\
5 \cdot 3 \\
5 \cdot 3 \\
1 \cdot 3 \\
2 \cdot 7 \\
5 \cdot 3 \\
6 \cdot 7\end{array}$ \\
\hline $\begin{array}{l}\text { Typable } \\
\text { Not typable } \\
\text { Rough strains }\end{array}$ & $\begin{array}{r}83 \\
71 \\
5\end{array}$ & $\begin{array}{c}52 \cdot 1 \\
-\end{array}$ & $\begin{array}{r}71 \\
48 \\
5\end{array}$ & $\begin{array}{c}56 \cdot 8 \\
- \\
-\end{array}$ & $\begin{array}{r}44 \\
29 \\
2\end{array}$ & $\begin{array}{c}58 \cdot 8 \\
- \\
-\end{array}$ \\
\hline Total & 159 & - & 124 & - & 75 & - \\
\hline
\end{tabular}

With the exception of 06 , frequency in wounds in this series mirrors the prevalence of carriage. This would suggest that the reservoir for the infecting serotypes is the patient population. This study did not include hospital personnel. Cooke et al. (1969) showed there is a change in the faecal flora during the in-patient period with the acquisition of new serotypes. Winterbauer et al. (1965) showed there was a higher faecal carriage rate of 04, 06 and 075 after 1 week in hospital and colonization appeared to rise significantly with the administration of antibiotics. It has been suggested by Cooke et al. (1970) that hospital food is one method whereby patients acquire new strains. Wound infection rate rises with the length of pre-operative stay and this is not related to the type of operation (Doig, 1969). Some patients may acquire new strains which are more communicable, or more infective than others, new strains to which they have less resistance, and are then more susceptible to sepsis. Nevertheless, the relationship of frequency of sepsis to carriage at the time of operation would remain the same. I believe it is important if considering endogenous wound infection, that we are aware of the possibility of the preparatory event of the acquisition of more virulent strains.

Returning to serotype 06 . What are the possible explanations for this having occurred twice as frequently in wounds as in carriage specimens? The strains could have been highly resistant to antibiotics, that is, hospital strains comparable to some Staphylococcus aureus strains. This is not the explanation, because one strain was sensitive, eight resistant to compound sulphonamides, one in addition resistant to ampicillin and the eleventh to sulphonamides, ampicillin, tetracycline and streptomycin.

There could have been an increased rate of acquisition, possibly from hospital food. It would be reasonable to expect the carriage rate to rise in this event.

The possibility of an outbreak of cross-infection must be considered, and I refer to cross-infection in the sense of the transfer of an organism to the wound from a source other than the patient and not to the acquisition of an organism in the bowel flora, and subsequent endogenous infection. The time-relationships of hospital stay, operation date and the time of development of wound sepsis are shown in Fig. 1. There is a distance of 45 yards separating the male and female wards and there are no shared facilities between them. From the Table it can be seen that none of the male patients were in the ward with any other. Of the female patients, 1462 and 1483 were in the ward at the same time as patient 1426 . The first two were carriers of serotype 06 at the time of operation. Organisms isolated from the wounds of patients 1426 and 1483 showed resistance to compound sulphonamides, but in the case of patient 1462 the pattern of resistance was in addition, tetracycline, ampicillin and streptomycin. Patient 1780 could have acquired the organism from patient 1691 and no serotype $\mathrm{O6}$ was isolated from the perineal specimen of patient 1780. Unfortunately, no bowel specimen was obtained. However, the strain from patient 1691 was resistant to compound sulphonamides whereas that of patient 1780 was sensitive. These findings show this is not an outbreak of cross-infection.

The fourth explanation is enhanced infectivity, and I have excluded the others. I will answer four questions with regard to pathogenicity in these wounds. Was there significant wound sepsis? You will remember in the definitions of the grades of wound sepsis (Table 1) Grade 1 is for minor sepsis and Grades 2 and 3 are for significant sepsis. The eleven cases being considered all had significant sepsis, five with Grade 2 and six with Grade 3. 


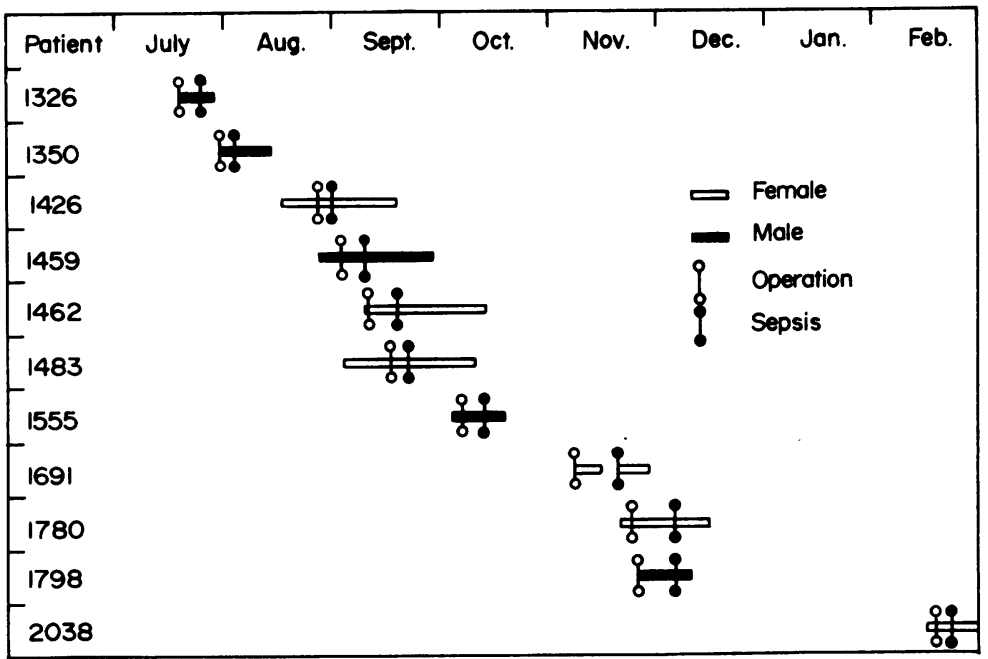

FIG. 1. Relationship of hospital stay, operation and wound sepsis.

TABLB 3. Organisms isolated from patients with Esch. coli 06 wound infections

\begin{tabular}{|c|c|c|c|c|c|c|}
\hline Patient & Nasal specimen & Perineal specimen & Operatio & pecimen & v & und specimen \\
\hline 1326 & 一 & - & \multicolumn{2}{|c|}{ NG } & & Esch. coli 06 \\
\hline 1350 & - & - & $\begin{array}{l}\text { Peritoneum } \\
\text { Lumen }\end{array}$ & $\begin{array}{l}\text { NG } \\
\text { Esch. coli } 06\end{array}$ & & Esch. coli 06 \\
\hline 1426 & No pathogens & Staph. aureus & $\begin{array}{l}\text { Peritoneum } \\
\text { Bowel }\end{array}$ & $\begin{array}{l}\text { NG } \\
\text { Esch. coli } 06 \\
\text { NLF }\end{array}$ & $\begin{array}{l}1 \mathrm{st} \\
\text { 2nd }\end{array}$ & $\begin{array}{l}\text { Esch. coli } 06 \\
\text { Esch. coli } 06 \\
\text { Other pathogens }\end{array}$ \\
\hline 1459 & No pathogens & Staph. aureus & $\begin{array}{l}\text { Peritoneum } \\
\text { Bowel }\end{array}$ & $\begin{array}{l}\text { NG } \\
\text { Not opened }\end{array}$ & $1 \mathrm{st}$ & $\begin{array}{l}\text { Esch. coli } 06 \\
\text { Ps. aeruginosa }\end{array}$ \\
\hline 1462 & No pathogens & $\begin{array}{l}\text { Esch. coli } 01 \\
\text { Esch. coli } \mathbf{O}\end{array}$ & Bowel & $\begin{array}{l}\text { Esch. coli } 06 \\
\text { NLF }\end{array}$ & $\begin{array}{l}1 \mathrm{st} \\
\text { 2nd }\end{array}$ & $\begin{array}{l}\text { Esch. coli } 06 \\
\text { Esch. coli } 06 \\
\text { Ps. aeruginosa }\end{array}$ \\
\hline 1483 & - & 一 & Bladder & $\begin{array}{l}\text { Esch. coli } 06 \\
\text { Strept. sp. }\end{array}$ & & Esch. coli 06 \\
\hline 1555 & Staph. aureus & Staph. aureus & Stomach & NG & $\begin{array}{l}\text { 1st } \\
\text { 2nd }\end{array}$ & $\begin{array}{l}\text { Esch. coli } 06 \\
\text { Esch. coli } 06 \\
\text { Staph. aureus }\end{array}$ \\
\hline 1691 & Staph. aureus & NLF & Small bowel & NG & $\begin{array}{l}1 \mathrm{st} \\
2 \mathrm{nd}\end{array}$ & $\begin{array}{l}\text { Esch. coli } 06 \\
\text { Esch. coli } 06 \\
\text { Proteus sp. }\end{array}$ \\
\hline 1780 & No pathogens & Staph. aureus & & & $\begin{array}{l}\text { 1st } \\
\text { 2nd }\end{array}$ & $\begin{array}{l}\text { Esch. coli } 06 \\
\text { Esch. coli } 06 \\
\text { Ps. aeruginosa }\end{array}$ \\
\hline 1798 & NLF & $\begin{array}{l}\text { Staph. aureus } \\
\text { NLF } \\
\text { Esch. coli } 06\end{array}$ & & & & Esch. coli 06 \\
\hline 2038 & No pathogens & - & $\begin{array}{l}\text { Peritoneum } \\
\text { Bowel }\end{array}$ & $\begin{array}{l}\text { NG } \\
\text { Not opened }\end{array}$ & & Esch. coli $\mathrm{O6}$ \\
\hline
\end{tabular}

-, No specimen; NG, no growth; NLF, non-lactose fermenter. 
Were the bacilli present isolated in large or small numbers? Although a quantitative method was not used, all wounds containing $\mathrm{O} 6$ yielded a moderate or heavy growth on initial culture.

Had other potential pathogens the opportunity to cause sepsis? Other potential pathogens were present at the time of operation in the majority of cases. This is shown in Table 3. Staph. aureus was present in the nose of two patients and a non-lactose fermenting organism in one. Five patients were perineal carriers of Staph. aureus and from perineal swabs two patients grew non-lactose fermenting organisms and two grew Esch. coli. One patient yielded Esch. coli type $\mathrm{O} 6$ and the other Esch. coli $\mathrm{O} 1$ and a non-typable one. There was no growth from peritoneal specimens when they were taken. In four patients the swab taken at operation yielded Esch. coli $\mathrm{O6}$. In addition potential pathogens were isolated from swabs taken at operation in three patients. In summary, in eight of the patients organisms other than Esch. coli were isolated from specimens obtained at the time of operation.

Were other pathogens found in the wound? In only one patient was a pathogen in addition to the Esch. coli serotype 06 grown from the first wound swab. In a further five, other pathogens were grown from the second swab in addition to Esch. coli O6. It is interesting that Staph. aureus was present in six patients at operation, but in only one case of wound sepsis was it isolated and then only from the second wound swab. No anaerobes were isolated from duplicate swabs examined by the hospital bacteriology laboratory.

There are a few indications in the literature that serotype $\mathrm{O} 6$ shows enhanced infectivity, but the authors do not enlarge on the observations. Gruneberg, Leigh \& Brumfitt (1968) set out the arguments against any special virulence for any of the commonly isolated $\mathrm{O}$-serotypes in urinary tract infections. However, they stated that in their series 06 was an exception as it occurred more frequently in urinary isolates than in faecal carriage specimens.

Borowski, Dzierzanowska \& Zaremba (1970) studying strains of Esch. coli isolated from patients with pyelonephritis stated that O6 predominated. Smith \& Gyles (1970) in a study of the effect of cellfree fluids prepared from human and animal strains of Esch. coli on ligated intestinal segments, commented that of the non-enteropathogenic human strains O6 : K13: H1 was outstanding in causing dilatation of segments.

In the present series serotype $\mathrm{O} 6$ occurred significantly more frequently in wounds than in carriage specimens. On the basis of the evidence presented to you I believe the only reasonable explanation is that these strains of 06 showed enhanced infectivity in wounds, compared with the other infective serotypes.

\section{Acknowledgments}

I wish to thank Professor D. M. Douglas for the opportunity to undertake clinical research and for his help and advice. I thank Professor J. P. Duguid for advice and guidance, Dr Joan Taylor for encouragement and Dr B. Rowe and his staff at the Salmonella Reference Laboratory, Colindale for the training in serological methods. Mrs P. Fotheringham for technical assistance. I am grateful to my medical and nursing colleagues. The Eastern Regional Hospital Board gave a grant towards this research.

\section{References}

Bettleheim, K.A. \& TAylor, J. (1969) A Study of Escherichia coli isolated from chronic urinary infections. Journal of Medical Microbiology, 2, 225.

Borowski, J., Dzierzanowska, D. \& Zaremba, M. (1970) The diagnostic and epidemiologic significance of nephropathogenic Escherichia coli serotypes. Archivium Immunologiae et Therapiae Experimentalis, 18, 322.

CoOKe, E.M., EwINS, S. \& SHoorer, R.A. (1969) Changing faecal population of Escherichia coli in hospital medical patients. British Medical Journal, 4, 593.

Cooke, E.M., Shooter, R.A., Kumar, P.J., Rousseau, S.A. \& FoulKes, A.L. (1970) Hospital food as a possible source of Escherichia coli in patients. Lancet, i, 436.

Davidson, A.I.G., Smylie, H.G., McDonald, A. \& Smith G. (1971) Ward design in relation to postoperative wound infection: Part II. British Medical Journal, 1, 72.

Dorg, C.M. (1969) Ch.M. Thesis, University of Dundee.

Grüneberg, R.N., Leigh, D.A. \& BRumfirt, W. (1968) Escherichia coli serotypes in urinary tract infections: studies in domiciliary, antenatal and hospital practice. In: Urinary Tract Infection (Ed. by F. O'Grady and W. Brumfitt), Chap. 9. Oxford University Press, London.

Kauffmaisn, F. (1969) The Bacteriology of Enterobacteriaceae. Munksgard, Copenhagen.

LANCET (1971) Leading article. Escherichia serotypes and renal infection. Lancet, i, 532.

LEPPÄNEN, M.K. (1958) Investigations of Escherichia coli in acute appendicitis and in normal appendicitis and faeces. Annales Medicinae Experimentalis et Biologiae Fenniae, 36, Suppl. 2.

Public Health Laboratory Service Report (1960) Incidence of surgical wound infection in England and Wales. Lancet, ii, 659.

Quick, C.A. \& BROGAN, T.D. (1968) Gram-negative rods and surgical wound infection. Lancet, i, 1163.

Smith, H. Williams \& Gyles, C.L. (1970) The Effect of cellfree fluids prepared from cultures of human and animal enteropathogenic strains of Escherichia coli on ligated intestinal segments of rabbits and pigs. Journal of Medical Microbiology, 3, 403.

VAHLNE, G. (1945) Serological typing of the colon bacteria with special reference to the occurrence of $B$. coli in man under normal and pathological conditions, particularly in appendicitis. Acta Pathologica et Microbiologica Scandinavica, Suppl. LX11.

Williams, R.E.O., Blowers, R., Garrod, L.P. \& Shooter, R.A. (1966). Hospital Infection: Causes and Prevention, 2nd edn. Lloyd-Luke, London.

Winterbauer, R.H., Turk, M. \& Petersdorf, R.G. (1965) Further evidence for epidemiological virulence of Escherichia coli. In: Antimicrobial Agents and Chemotherapy, p. 71. 